\title{
Economic tools of media policy for the preservation of media pluralism: An analysis of solutions adopted in Austria, the Czech Republic, France, Germany and Italy
}

\author{
M. Jas-Koziarkiewicz, E. Stasiak-Jazukiewicz \\ University of Warsaw, \\ Krakowskie Przedmiescie 26/28 00-927 Warsaw, Poland
}

For citation: Jas-Koziarkiewicz M., Stasiak-Jazukiewicz E. Economic tools of media policy for the preservation of media pluralism: An analysis of solutions adopted in Austria, the Czech Republic, France, Germany and Italy. Vestnik of Saint Petersburg University. International Relations, 2018, vol. 11, issue 4, pp. 415-435. https://doi.org/10.21638/11701/spbu06.2018.407

\begin{abstract}
Media policy makers are looking for safeguards for freedom of expression other than statutory guarantees. The economic tools of media policy are one of the forms they use. The presented analysis is based on the assumptions of constructivism. The adoption of this theoretical perspective is also connected with the authors' accepting the statement that shared norms, values and ideas are strengthened, consolidated, worked out, contested and changed in social processes. The starting point for the adopted research strategy was a case study. The article presents indirect and direct subsidies supporting media pluralism in Austria, the Czech Republic, France, Germany and Italy. All of the analysed countries decided to use this form of media support, but the scope of assistance provided is different. The media are most strongly supported by France and Austria while in Italy the level of support can be defined as medium and economic interventions on the media market are taken to the smallest extent by Germany and the Czech Republic. The analysis was supplemented by a discussion of the relationship between media ownership and economic and political elites. The economic and political elite connections with the media, as indicated in the text, are the best recommendation for countries to use economic forms of supporting media pluralism.
\end{abstract}

Keywords: media pluralism, media policy, indirect and direct subsidies, Austria, the Czech Republic, France, Germany, Italy.

\section{Introduction}

Pluralism is a conditional value the scope, limits and criteria of which are conditioned by politics [1, p. 506]. This is reflected in the media policy of states which, by adopting legal regulations, make efforts to secure it. Manuel Puppis has distinguished two regulatory approaches: "the competition or market approach, endorsing economic regulation to prevent market failure, and the interventionist or public regulation approach, involving an active media policy" [2, p.13]. Activities under the second approach relate to: media organisations (public media, setting rules for private broadcasters), media financing (subsidies, support for audiovisual production, financing of public media), their ownership (regulations regarding concentration), distribution (must-carry obligation) and content (content requirements). The indicated areas of state activity justify the assessment that

(c) Санкт-Петербургский государственный университет, 2018 
media policy makers are looking for safeguards for freedom of expression other than statutory guarantees. The economic tools of media policy aimed at limiting the process of media concentration are one of the forms they use.

\section{Methodological assumptions}

The presented analysis is based on the assumptions of constructivism. In this theory, for the construction of social reality, the ideas and values are important, such as undoubtedly media pluralism. The adoption of this theoretical perspective is also connected with the authors' acceptance of the statement that shared norms, values and ideas are strengthened, consolidated, worked out, contested and changed during social processes. This approach puts an emphasis on data analysis ascribed to the social context [3, p. 12]. In the case of media policy, the social consequences of decisions are particularly important. In the article it was highlighted in the summary but it also found a special expression in the presentation of information on the links between the world of economics and politics with the media sphere.

The starting point for the adopted research strategy was a case study. This method "explores a real-life, contemporary bounded system (a case) or multiple bounded systems (cases) over time, through detailed, indepth data collection involving multiple sources of information $\langle\ldots\rangle$ and reports a case description and case themes" [4, p. 97]. Analyzes carried out using this research strategy "to refer to both within-case analysis of single cases and comparisons among a small number of cases" [5, p.20].

Five countries were analyzed: Austria, France, Italy, Germany, and the Czech Republic. The choice of states was not accidental. One of the selection criteria was the diversity typical of the European market. Selected states represent media markets of various sizes, the process of liberalization of these markets has been variously different, they have their own media capital with various investment possibilities, implement various models of the media system, they are characterized by different degrees of democratization of public life and different corporate culture.

The next selection criterion was the state policy regarding the use of economic media policy tools. Based on the literature of the subject, the so-called crucial case studies [6, p.2] were chosen - countries strongly supporting the media (Austria, France) - and the state that does not have an active policy in this area at central level (Germany). The choice of the Czech Republic was determined by the dominance of regulations protecting the national market from the presence of strong foreign capital, different from those adopted just after the Second World War in France or in the 1980s in Austria. Italy is a special case. By 2016, the state actively supported media pluralism through the economic tools of media policy, and now its policy can be described as passive. The leading research method was complemented by a comparative perspective. The combination of both methods is not surprising, as described by Arend Lijphard, „certain types of case studies can even be considered implicit parts of the comparative method" [7, p. 691].

The study was based on the analysis of legal acts and literature on the subject, as well as primary sources, such as press materials. The issues of the organisation, principles of financing and functioning of public media were not analysed. Legal regulations limiting media concentration were also omitted. This issue was presented by the authors in a separate article [8]. 
The aim of the analysis was to determine the economic tools of media policy supporting media pluralism in Austria, the Czech Republic, France, Germany and Italy. In the course of the analysis, answers to the following research questions were sought:

- How is media pluralism defined?

- What are the links between media ownership and political elites?

- What are the links between media ownership and economic elites?

- What forms of direct and indirect media support are used in selected countries?

\section{Pluralism and media concentration}

The media are at the same time both an economic venture and institutions that pursue important social goals. Their dual nature leads to conflicts of values in the media policy of states $[9$, p. 53], which becomes especially visible in the case of media concentration and attempts to reconcile "two 'competing' interests: safeguarding competition on the one hand, and ensuring media plurality/diversity/pluralism on the other" [10, p. 98]. According to the assessment of most researchers, there is "a strong link between the level of media concentration and media pluralism and/or media diversity" [11].

The preservation of media pluralism is one of the main goals of media policy in democratic states, moreover "the existence of a sufficiently plural and diversified media system represents one of the basic preconditions for a political regime to be considered democratic" [12, p. 424]. Most often, pluralism is reduced to the diversity of media (social perspective) and the freedom of their economic activity (economic perspective). As Beata Klimkiewicz assessed, these perspectives prompt researchers to consider issues in various perspectives: "within media systems, media entities, political and legal conditions, journalistic and organisational practices, media content", and also reducing media pluralism to "conceptual alternatives: external/internal, organised/spontaneous, balanced/polarised, open/proportional, cultural/political" [13, p.2]. Dichotomie external/internal pluralism consists of "two major normative approaches that come to the fore in national and European policy discourses, as well as social science literature" [14] (see also: [12; 13; 15-19]), although there is no consensus among researchers regarding their conceptual scope.

External pluralism is defined in the reference to the diversity of information sources [20], the multiplicity and diversity of media institutions or organisations "reflecting the points of view of different groups or tendencies in society" [16, p.29] or it is limited to the existence of independent, autonomous media entities [21, p.51]. Beata Klimkiewicz noted that this pluralism is also associated with the use of the media. She defines external pluralism as "the existence of a wide range of media outlets, organisations, and services reflecting various points of view, recognising diverse cultural representations, and offering different ways of interaction and use" [13, p. 906]. Tadeusz Kowalski completed this definition with another aspect: the diversity of content (including topics, concentration "on the type of content or a specific point of view") offered by independent, autonomous media and their owners [18, p. 21].

In the case of internal pluralism, greater compatibility among researchers is noticeable. They all emphasise that internal pluralism occurs at the level of a media institution. Klimkiewicz related it to the diversity of media content [13, p.46]. Hallin and Mancini brought it to pluralism "achieved within each individual media outlet or organisation" [16, p. 29]. The broader definition was proposed by Tadeusz Kowalski: "the diversity of 
content, services and sources of their origin within a given media unit, offering as a result a broad spectrum of opinions, points of view, representing and evaluating social, ethnic, political and cultural issues" [18, p. 22]. The issue of the diversity of media content, "that is, media fulfilling various social functions and presenting different views, also on political topics" was also emphasised by Ewa Stasiak-Jazukiewicz [21, p. 51].

Concentration of media ownership may pose a threat to pluralism, including for "a) sufficient programme diversity (variety of programme content); b) sufficient access to information; and c) sufficient balance in the provision of news and information" [22, p. 661]. This phenomenon may, therefore, lead to a reduction of the market of ideas, limit the possibility of obtaining information about public issues, limit access to the media, and it may lead to the lack of criticism towards the authorities [21, p. 18]. Thus, when threats associated with the concentration of media ownership concern the following spheres: economic, political, cultural and national, in particular, the local media markets are at risk [23, p. 477].

Concentration on the media market becomes particularly dangerous when the owners or media groups are associated with political and/or economic entities [24, p. 37 $]^{1}$.

\section{Relations between media ownership and political and economic elites}

The main functions of the media in the democratic system include: informing (the media are guarding the openness of public life), controlling (the media protects citizens against the abuse of economic and political elites) and organising public debate (they indicate both problems bothering the public and views on how to solve them). The concentration of media ownership poses a threat to the correct implementation of these functions. The links between the media and the political elite are particularly dangerous, because they create the possibility of manipulating public opinion [24, p. 37]. It threatens to influence the procedures for the appointment of editorial staff. It can lead to the disappearance or limitation of pluralism of opinion, e. g. when particular media are preferred when applying for state subsidies or are the main or only beneficiaries of state-owned advertising [25, p.29]. In spite of the concentration restrictions in the analysed countries, these dangers have not been avoided.

A similar danger exists in the case of media connections with economic elites, and especially with oligarchs. According to Arystoteles, an oligarchy is usually an implicit governance of the few with rich financial and organizational resources, operating mainly in its own interest [26]. Anders Åslund stressed that the political threat with the consequences for the economic system are not the oligarchs themselves but their relations with the state institutions [27]. A well-known example of such political problems was the long-term career of Silvio Berlusconi in Italy. Oligarchisation is becoming an international norm [28]. An indicator of asset concentration underlines it. It is favored by unprecedented circum-

${ }^{1}$ Strong relationships between the media and political and economic spheres are visible in Hungary, where the media are taken over by politically engaged owners. András György Vajna, the government commissioner for the Hungarian film industry, purchased the leading TV2 TV station in 2015, whereas the political advisor of Victor Orbán, Árpád Habony, is the owner of the free daily "Lokál" and the information portal 888.hu. Hungary lacks transparent rules for the distribution of state-owned advertising. In addition, the amendment to the media law introduced in 2013 limits the rights of journalists to information about development projects and spending public funds. Journalists of private television stations cannot register plenary meetings of the parliament - in their reports they must use recordings made by a company acting on behalf of the parliament. 
stances that accompany, for example, political changes, when state resources are available to politicians. In addition it is favored by the rapid development of capitalism, institutional weaknesses and corruption. Factors hampering oligarchisation are: egalitarian society, influential trade unions as well as free media tracking irregularities [29]. Among other things, the last of these factors justifies the interest of the economic elites in their own media. In spite of the concentration restrictions in the analyzed countries, these dangers have not been avoided, which is clearly illustrated by the information presented in Table 1 .

Table 1. Relations between media ownership and political and economic elites in Austria, the Czech Republic, France, Germany and Italy

\begin{tabular}{|l|c|c|c|c|c|}
\hline & Austria & $\begin{array}{c}\text { Czech } \\
\text { Republic }\end{array}$ & France & Germany & Italy \\
\hline \multicolumn{7}{|c|}{ media connections with economic elites } \\
\hline media oligarchisation & & $\mathrm{X}$ & $\mathrm{X}$ & & \\
\hline $\begin{array}{l}\text { legal protection, independence of } \\
\text { journalists from media owners }\end{array}$ & & & $\mathrm{X}$ & $\mathrm{X}$ & \\
\hline \multicolumn{2}{|c|}{ powiązania mediów z elitami politycznymi } & $\mathrm{X}$ & \\
\hline prawne ograniczenie własności państwowej & & & $\mathrm{X}$ & $\mathrm{X}$ \\
\hline legal restriction of property by a politician & & $\mathrm{X}$ & & \\
\hline legal limitation of party property & & $\mathrm{X}$ & & & \\
\hline reguły stosowania reklamy państwowej & & & $\mathrm{X}$ \\
\hline
\end{tabular}

S o u r c e: own study.

\section{Media oligarchisation}

There is no media oligarchisation in Austria. In the Czech Republic, however, the links between the media and the economic elites arouse anxiety. As examples of this kind of connections, we can recall, among others, billionaire Ivan Zach, owner of the financial group Ges, who is the main shareholder of the television station Prima; Daniel Křetínský, co-owner of the football club AC Sparta Praha and energy holding EPH, who together with Patrik Tkáč owns Czech Media Invest a.s., which is the sole shareholder of the Czech News Center, which publishes, among others, the two most widely read tabloids "Blesk" and "Aha!"; Zdenek Bakala, former owner of the mining complex, which is the owner of the economic daily "Hospodárské noviny", the weekly "Respekt" and the information service [30].

The "oligarchisation" of the Czech media has caused a public discussion in this country about the motivations of the new owners. It was pointed out that it results from a desire to use the possibilities of shaping public opinion to fulfil their business and political ambitions. As an example confirming this assessment, we can recall Babišs influence on one of the editorial offices after it did not present information about the ANO conference [31, p. 19]. This assumption is also confirmed by the Penta Investments declaration: "The potential of commercial media cooperation with our companies was the key reason for entering the media industry. As an investor, we want to provide our media companies with financial 
stability in exchange for high professionalism and quality of journalistic work in creating and supporting a social environment" [32]. This situation can be summed up in the words of Vaclav Stetta, formulated in 2010 and still valid, stating that you can identify "growing interest of leading Czech businessmen and industrialists in establishing their own media empires and exercising through them their business PR and political influence, becoming thereby akin to the 'media moguls' known particularly from the Southern European countries" [33, p. 882]. It is worth recalling that the indicated Czech-Slovak company invests in the medical sector, in the real estate market, financial services in the Czech Republic, Slovakia, Poland and Germany. They ownVltava Labe Media, the company publishing the largest regional newspaper in the Czech Republic "Denik" and the magazine "Astrosat" and two Slovak publishing houses News and Media Holding and Petit Press.

In France, the majority of media entities belong to large industrial or retail and commercial conglomerates. Altice, an international telecommunications company operating in Israel, the USA, the Dominican Republic, Portugal and France, is the publisher of newspapers "L'Express" and "Libération" and owns a cable TV Numericable. Bolloré, an international transport group, present in the automotive industry and an energy distributor is a $60 \%$ shareholder of Havasa and from 2017 the owner of the media giant Vivendi. Bouygues, a company operating in the construction sector, is the main shareholder of the largest private TV station TF1. And above all, Lagardère, a holding company operating in the automotive and aerospace industries, a shareholder of the European Space Agency and aviation EADS, owns 13 press titles, including "Elle" and "Paris Match" and 80 in the world, 26 radio stations and 17 television stations (see also [34, p. 114-116]).

In Germany, in the first half of 2017, only 5 media companies had a $55.1 \%$ share in the consumer market. They were: public TV broadcasters ARD (21.2\%) and ZDF (7.4\%) and private media groups Bertelsmann (12\%), Springer (7.9\%) and ProSiebenSat.1 (6.7\%) [35]. Unlike France, the activity of these groups is basically limited to the media industry (printing, paper, distribution, advertising agencies, record companies, film studios) (see also [36]).

The Italian media system is often indicated as an example of a too strong connection between the economic and political spheres and the media. No legal restrictions have been introduced in this area.

\section{Legal protection, independence of journalists from media owners}

The independence of journalists from media owners is poorly secured in the Austrian system. The Code of Ethics in Journalism states that the economic interests of the media company owner should not affect editorial work [37]. However, there are no legal safeguards stating that decisions regarding the appointment and dismissal of the editorin-chief must be made irrespective of the commercial interests of media organisations. Editorial authorities do not defend editorial charters, only TV stations and radio stations are obliged to introduce them [38].

Czech and Italian journalists are not protected by either real or theoretical rules against submission to the owners.

French journalists are protected against the influence of the owners by the clause of conscience (Brachard's law establishing the journalist's professional status) [39], allowing refusal to prepare material in which they would have to express views contrary to their beliefs, protecting them at the same time also from being dismissed for the refusal. In 
addition, the law provides for the possibility of voluntary departure in the event of a "significant change in the orientation" of the letter while retaining the right to compensation in the amount of one month's payment for each year worked. Similar financial benefits are foreseen for a journalist leaving because of a change in the owner of the magazine (assignment clause). Editors' employees, on the other hand, have no influence on the appointment and dismissal of the editor-in-chief.

These regulations, however, do not guarantee the independence of journalists who censor their own materials or are subjected to pressure from corporations or media owners. An example of this kind of impact was the refusal of the Bolloré Group to publish a text on the intervention of police officers against the Roma, under the pretext that it might be particularly unpleasant for the French, or the lack of information on accusations against Serge Dassault for buying votes in the titles issued by his company [40, p. 31].

German journalists were protected against the dictates of employers by a strong trade union and intra-factorial statutes. Media convergence, progressing press crisis caused by the economic crisis and drop in readership, development of civic journalism caused that the majority of media workers in Germany of the second decade of the 21st century are self-employed (Outsourcing), flat-rate workers (Pauschalist) and freelancers, not bound by any form of contract for work with any media entity [41]. According to the data of the Bundesverband Deutscher Zeitungsverleger (BDZV), in 2017, nearly 10,900 full-time journalists and over 900 volunteers were employed in the daily press and weeklies against over 15,300 full-time editors and 1,370 volunteers in 2000 [42, p. 270; 43].

\section{Legal restriction state media ownership}

Only in Germany, state media ownership is prohibited except for the media addressed to a foreign audience. For example, Deutsche Welle has such a status, it is directly supervised by the Federal Minister for Culture and Media [44], which also results in financing the activities of the institution - in 2017 at the level of EUR 325 million [45].

\section{Legal restriction on media possession by politicians or political parties}

In Austria, although state and party property in the media is not prohibited, there are no electronic media belonging to or associated with political elites, and the share of the daily press associated with political entities is below $0.5 \%$.

In the Czech Republic, despite the amendment to the law on conflict of interests adopted in 2017 [46], prohibiting members of the government from owning shares in the media and the companies owned by them (more than 25\%) from using public funds [14], Andrei Babiš, from January 2014 to May 2017, Deputy Prime Minister and Minister of Finance in the Bohuslav Sobotka government, and since December 2017 the Prime Minister of the Czech Republic, owned Agrofert. It is an international group of 250 enterprises operating in agriculture, the chemical and nutrition industry. It also publishes significant Czech newspapers (as part of the Mafra group, among others "Mladá fronta dnes", "Lidové noviny" and free "Metro"), it runs informational internet portals (iDnes.cz, 5pus2.cz), radio stations and music TV station Ócko. The fact that a politician owns a media group raises concerns about the possibility of him influencing the media message, moreover, Babiš himself, among the premises for the group's acquisition, indicated that the media "wrote lies about him" [30, p. 12]. Doubts also arise from the reduction of the VAT rate on 
newspapers, magazines, bulletins and other periodicals (up to 10\%) in March 2017 - in the period when Babiš was the Minister of Finance [47] ${ }^{2}$.

In France, despite the legal prohibition of media possession by political parties and politicians, some of the media companies are directly connected with them. Serge Dassault (Serge Bloch) is an example, being the owner of the Dassault Group operating in the armaments industry (the manufacturer of Rafale) and a Senator on behalf of the Republicans (LR) and at the same time the owner of the daily "Le Figaro", magazines and internet portals. Another example is Jean-Michel Baylet, who heads the group issuing, among others, regional dailies "La Dépêche du Midi", "L'Indépendant", and the sport bi-weekly "Midi olympique". Baylet was associated with the Radical Left Party, deputy an MP, a Senator for several terms, and additionally a Minister between 1990-1993 and 2016-2017.

In Germany the ownership of political parties in media companies must be reported to the Bundestag chairman and these reports are published. The relationships of media owners with political elites are, however, clear. For politicians to be publishers or editors of the opinion-forming press titles is not just a phenomenon of the past as, for example, was the case with Rudolf Augstein, the publisher of the Der Spiegel magazine and a member of the FDP, from the lists of which he got to the parliament in 1972. Such links can be observed now as well. Thus, Friede Springer, the wife of the deceased creator of the group, has been a member of the national parliament in Berlin for years on behalf of the CDU, and as a member of the Federal Assembly, she was elected presidents of the republic five times in the following years: 2004, 2009, 2010, 2012 and 2017. In the seven-member board of trustees of her foundation (Friede Springer Stiftung) sits the former president Horst Köhler and Joachim Sauer, the husband of Angela Merkel [48].

Over the years, Silvio Berlusconi, acting as the prime minister of Italy in 1994-1995, 2001-2006, 2008-2011, had shares in the Mondadori publishing house and, above all, the largest sharepackage in the Mediaset group - a company which, apart from RAI, remains the most important player on the television market. In 2017, Mediaset stations ranked second in terms of audience coverage (31\%) and RAI ranked first with $36 \%$ [49, p. 8].

Berlusconi's practices, combining the economic, political and media power in the hands of one man [50, p. 82], became an infamous example of how to "destroy" democracy. The ban contained in the so-called Frattini Act - which does not allow the holders of some public offices (prime minister, minister) to undertake certain activities, including economic activity - remained unchanged [51, art. 2]. Even changes in the government have not led to a reform of the legal framework regarding media ownership, and moreover, one can observe "political unwillingness to regulate the technological development in a way that favors pluralism" [52, p. 180].

\section{Rules for the use of state and public advertising}

In Austria despite the 2011 Act on transparency of the media structure [53], the rules for the use of public institutions advertisements were not specified. Only the obligation to provide the public with information on the amount of advertising expenditure has been introduced. In practice, the advertising orders are directed mainly to selected media, in particular the "Kronen Zeitung", "Heute" and "Österreich" dailies, without observing, for

2 This form of media support is used in many European countries. In this case, however, it is also used by the group belonging to Babiš. 
example, the principle of proportionality to market share. The indicated newspapers in 2016 received almost $24.5 \%$ of funds allocated for publicity in the media. Kronen Zeitung received EUR 19,381,347, Heute - EUR 13,208,731 and Österreich - EUR 9,979,720 [54]. In total, the expenditure on inserts and public administration ads in 2016 amounted to over EUR 175 million [54]. It is also controversial that the information on some part of the expenses, according to the estimates up to EUR 60 to 100 million, is not made public. This is due to the threshold of EUR 5,000 introduced by the Act, according to which in the case when the orders do not exceed this amount, information on them is not published [55]. It should be added that there are family connections between the first two of the listed titles. Christoph Dichand is a co-owner of "Kronen Zeitung" and his wife Eva Dichand publishes "Heute" [56, p. 102].

In the case of the Czech Republic, there are no clear rules on the distribution of advertising from public institutions to the media. There is also no obligation to inform about the amount of expenses for this purpose.

The German legislation did not foresee the obligation to publicise information on advertising expenditure. The amount of expenditure for this purpose was estimated at EUR 16 million in 2016 [57].

Italy's policy regarding state-owned advertising deserves special attention. In Decree $\mathrm{N} 177$ of July 31,2005, it was specified that the advertising plan of public institutions should specify the schedule of how the advertisement would be broadcast and the budget that would be allocated to each type of media. The distribution of budgetary amounts is supervised by the AGCOM media market regulator (Autorità per le garanzie nelle comunicazioni). Each ministry should allocate funds for advertising in the following proportions: $50 \%$ for newspapers and national radio stations; $15 \%$ for private local television and local radio stations operating on the territory of EU Member States; and $35 \%$ for other media [58, art. 41]. It is worth noting, however, that these advertisements represent a small share in the earnings of the media industry and have no impact on the market.

\section{Media support by the state}

Media subsidies are one of the instruments to ensure pluralism. They help keep on the market the media, that would otherwise lose the competitive struggle with large corporations. The discussion on the legitimacy of subsidising the media did not result, however, in constructive conclusions. There are two opposing views on the impact of public intervention in the media industry. The first is based on the theory of public service. It is represented by such theoreticians as: Todd Gitlin, Edward S. Herman, Noam Chomsky, Adam Gamble and Takesato Watanabe. They say that the government is obliged to support the diversity of opinions and mitigate the consequences of a free-market game leading to the collapse or takeover of less-effective media [59-61]. In conrast, Mauro Wolf negatively evaluates state intervention in market law. He is afraid that using the subsidy will contribute to building government-friendly media. The double-voice on this form of state influence on the media market can be expressed in two positions: 1) the assessment that it distorts the mechanisms of the free market, 2) the assumption that this solution makes it possible to realise socially important goals. Public aid for the media takes the form of both direct financial support and indirect subsidies. In the countries selected for the analysis, the subsidy system is developed variously, most elaborately in France (Table 2). 


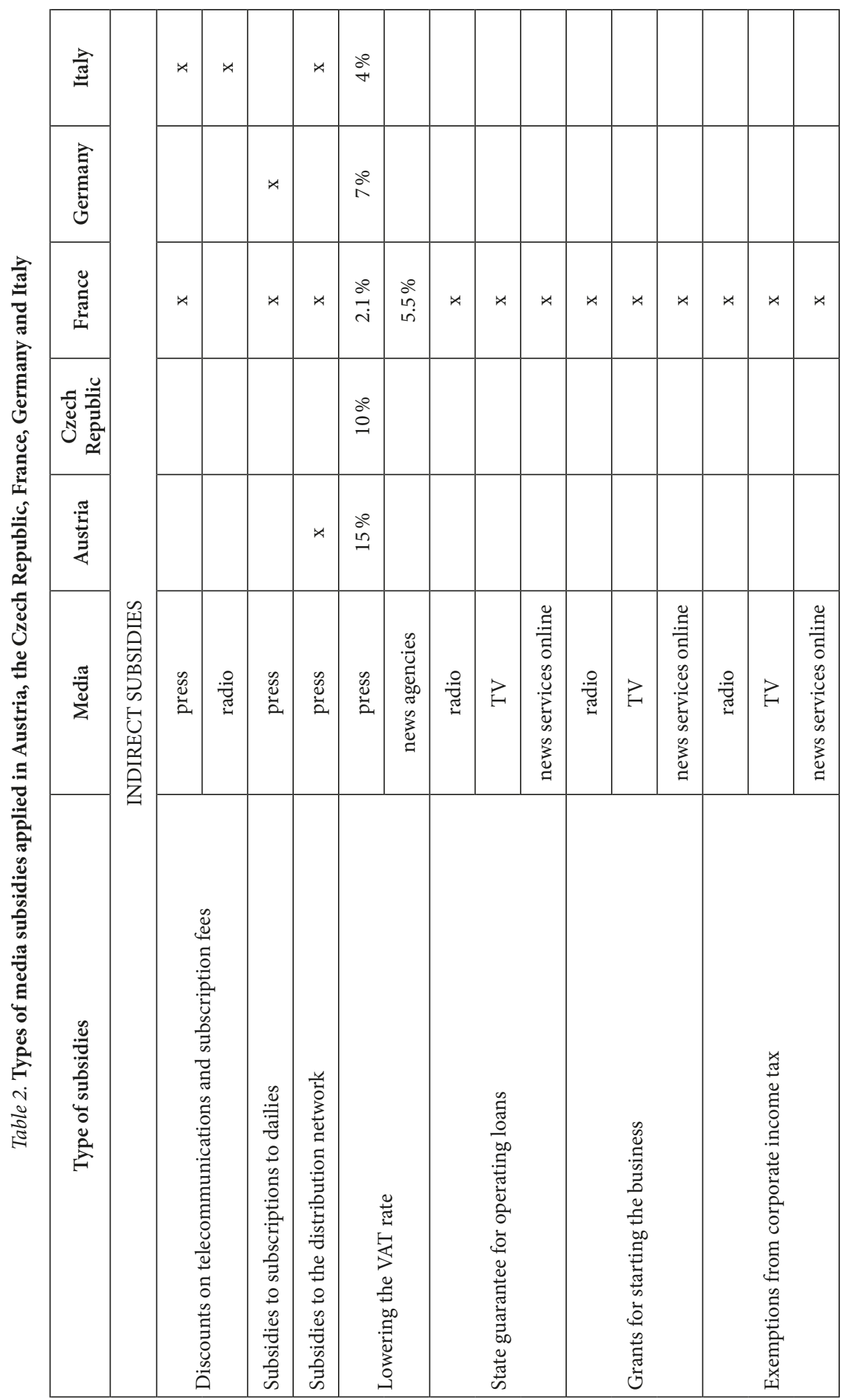




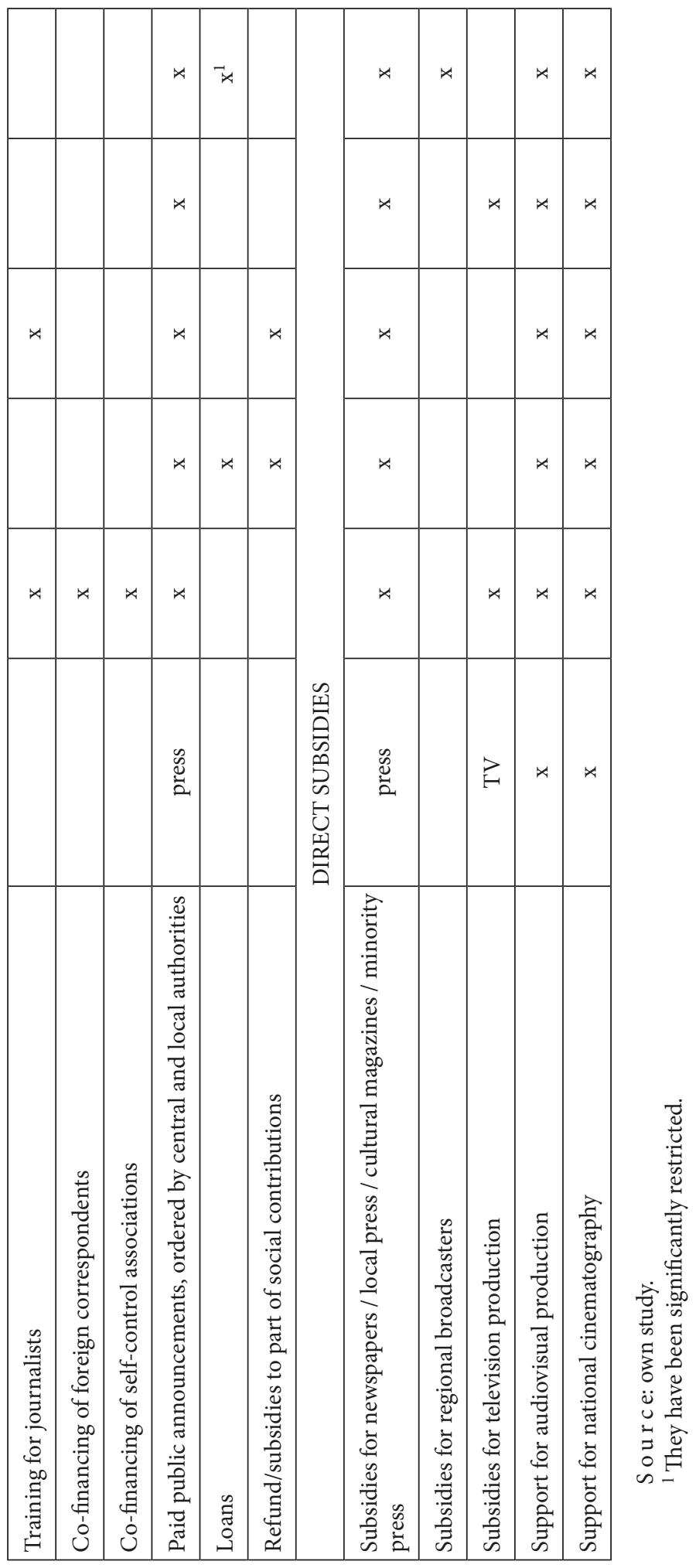


Interesting solutions in the field of subsidising media activities were introduced in Austria. The solutions adopted are elaborate and allow for granting public aid to all types of media, which allows Austria to be included, next to, among others France, in the group of countries that use the subsidies in media policy to its fullest extent [62, p.29].

The state's obligation to provide assistance to the media has been included in the Constitution [63], in the acts and executive acts, while the types of media and the form of support provided to them were specified. The press receives co-financing from several funds: 1) funds for the promotion of journalism (Publizistikförderung) based on the Act of 1984 [64]; and specified in the 2003 Act on press support [65];2) funds for sales and distribution; 3) funds for preservation of regional press diversification; 4) funds for improving the quality and securing the future of the media; 5) funds supporting organisation of media self-control. Under the last four funds, EUR 8,912,000 was distributed to publishers in 2017 [66; 67]. In the case of the fund for promotion of journalism, the amount of funds transferred were lower and in 2017 amounted to EUR 340,000 [66].

Funds for preservation of regional press diversification are meant to strengthen the media pluralism. This goal was achieved by excluding the possibility of applying for subsidies for titles with a dominant position in the country and/or the region. In the case of the publicity promotion fund, the main purpose of the regulation is to ensure diversification of the periodical press, including regional press, and as a result to guarantee pluralism (more: [68]).

Funds for the media are also transferred from five special funds, which ensure the implementation of specific tasks or provide the society with certain values. They are allocated to commercial broadcasters - 1. Digitisation Fund (Digitalisierungsfonds) - every year from 2009, EUR 500,000; 2. Austria Television Fund (Fernsehfonds Austria) in the amount of EUR 13.5 million in 2016 [69]; 3. Non-Commercial Broadcast Support Fund (Fond zur Förderung des nichtkommerziellen Rundfunks) - EUR 2,901,863 [70]; 4. Private Broadcasters Support Fund (Fonds zur Förderung des privaten Rundfunks) - EUR 15 million in 2016; 5. Self-Regulatory Fund for Media in Commercial Communication (Förderung von Selbstkontrolleinrichtungen bei der kommerziellen Kommunikation) EUR 50,000 every year from 2009.

Two of the funds indicated are of particular importance in the context of media pluralism. As part of the Non-Commercial Broadcast Support Fund, the funds are allocated to non-commercial broadcasters to provide a variety of high-quality programs. They are to contribute, among others, to the promotion of Austrian culture, national and European consciousness and education. Therefore, the support is granted to the broadcasters, whose offering is often less competitive due to the content, but it fulfils socially important functions. The Private Broadcasters Support Fund is to support the development of a dual media system, ensure the diversification of the programming offer, including local and regional broadcasters, and the high quality of the programming content [71].

In addition, in Austria, cinematographic production is supported by the FISA Film Production Support Program, which has an annual budget of EUR 7.5 million [72]. As part of the fund, one can get, among others a grant of $20 \%$ of the production costs and a $25 \%$ subsidy for being an Austrian production company. Meeting the criterion of spending and the so-called cultural test is the condition for co-financing.

The solutions adopted in the Czech Republic differ significantly from those in Austria. The basic form of support for printed media consists of indirect support in the form 
of a reduced tax rate for newspapers, magazines, bulletins and other periodicals. A $10 \%$ rate for them has been introduced (from March 15, 2017, earlier it was 15\%) [69], other products being subject to a $21 \%$ rate.

Funds for publishing initiatives are transferred by the State Culture Fund of the Czech Republic (Státní fond České republiky). It is a public fund entrusted with tasks in the field of supporting projects related to culture, and co-financing media projects is only a part of the tasks carried out. Its activity is financed, among others, from subsidies from the state budget, from own revenues from the sale of materials issued by the Fund, interest on loans granted to applicants, public collections and lotteries, from funds raised from international institutions and organisations, and from donations. The Fund's tasks include activities for the implementation of specific cultural projects, including the provision of financial support to periodicals and non-periodicals of significant importance to Czech culture, as well as to minority publications. The funds are transferred as targeted subsidies, loans or refund of contributions. The applicant may maximally receive up to $2 / 3$ of the grant. Natural and legal persons with registered office or permanent residence in the Czech Republic are eligible to apply for the support. If the applicant is a Czech company but is co-owned by a foreign entity, it is possible to obtain co-financing provided that the foreign entity holds less than $50 \%$ of shares [73].

Support is also directed to the audiovisual sector. The State Fund for Cinematography (Státní fond cinematografie) decides on subsidies, among others, $20 \%$ deduction of expenses related to the purchase of goods and services incurred in connection with the production of a film in the Czech Republic, $66 \%$ allowance of tax paid in the Czech Republic in the case of remuneration for foreign servicing and casting [74]. Co-financing is granted subject to the fulfilment of minimum criteria, including the length of cinematographic production and minimum expenditure in the Czech Republic and the passage of the socalled cultural test. The fund has a budget of EUR 51 million per annum [75].

The French subsidy system is extensive. The country has been developing forms of assistance for the press since 1796. Initially, they relied only on introducing privileged postal rates. They have gradually developed it into an expensive system of promoting a pluralistic media landscape, which in 2015 already included 326 out of 3,675 press titles registered by the Joint Publication and Press Agency ${ }^{3}$. Not only national titles with information content or those with low advertising content are supported, but all newspapers and some magazines with educational values addressed to young people. In the budget act for 2017,

${ }^{3}$ La Commission paritaire des publications et agences de presse is an independent administrative body composed of representatives of the state administration and the media environment (appointed at the request of journalistic associations), it is responsible for issuing opinions on economic benefits (postal and fiscal tariffs) to the information press and online press services, and grants the status of an information agency. The activities of the commission are governed by Decret N 97-1065 of November 20, 1997, as amended in 2016 (Décret N 97-1065 du 20 novembre 1997 relatif à la commission paritaire des publications et agences de presse). In particular, it is responsible for: adherence by news and online information services, to the criteria contained in Chapter 17 of Annex N 2 of the General Tax Code; controls the weekly edition of periodicals qualified for co-financing under Art. 9 of Decree N 2012-484 of April 13, 2012 on reforming aid to the press and strategic fund for the development of the press; controls the fulfilment of the following criteria: low advertising share in information revenues of national dailies included in Art. 1 point b-1 of Decree N 86-616 of March 12, 1986 and the criterion of coverage of regional and local titles provided for in art. 3 points 2 of Decree N 2004-1312 of November 26, 2004; reviews the situation of organisations registered on the list of news agencies. Entries entitling to discounts in the registers are valid for a period of five years, whereby information is verified on an ongoing basis and the register is updated. 
EUR 127,84 million was allocated to aid for the media. It included: EUR 5 million for new media entities (Le Fonds de soutien à lémergence et à l'innovation dans la presse); EUR 16 million for regional and local press (Les aides concourant au maintien du pluralisme ); EUR 9.8 million for network information agencies; EUR 1.58 million for informational community media (Fonds de soutien aux médias d'information sociale de proximité); EUR 4 million for subsidies to modernise the press distribution network (Les aides à la diffusion (aides directes)) and, after deduction of the postal subsidy, additional subsidy for VAT and subsidies to social insurance premiums for journalists, the rest, approx. EUR 60 million - for direct support for the press (Le Fonds stratégique pour le développement de la presse) [76]. The amount of subsidies for individual titles varies, depending on the effort and space allocated to advertising. The upper limit amounts to $10 \%$ of the annual costs of maintaining the title. For example, in 2015 EUR 7,770,562 was allocated to the daily "Aujourd'hui en France", the national edition of the Paris boulevardi "Le Parisien". EUR 1,000,805 went to the regional "La République des Pyrénées" closing the list of the 20 highest-subsidised daily newspapers [77].

Similarly to subsidies dedicated to the press, forms of financing film productions are developed. One of the forms of support consists of a $30 \%$ tax break for qualified production expenses, and there are 41 local film commissions, which also offer support [78].

In Germany, media policy is conducted by the federal states. They also subsidise media production as needed. Nevertheless, the federal administration feels responsible for the media. The Federal Minister for culture and media is responsible for adapting media legal regulations to current social needs, promoting cultural and media institutions, representing their interests on the international arena. It has a substantial budget for this purpose, which in 2017 amounted to EUR 1.6 billion [45]. As part of the promotion, various media projects are subsidised. State subsidies are mainly granted for the production of films and are distributed according to transparent procedures [79]. Established in 2007, the German Film Production Financing Fund (Deutscher Filmförderfonds - DFFF) in 2017 co-financed 100 film productions to the amount of EUR 57.3 million and from the establishment of DFFF until the end of 2017, 1,187 productions worth EUR 651 million were financed [Deutscher Filmförderfonds]. The refund of $20 \%$ of the costs incurred in Germany is granted to every producer registered in Germany. The grant is equal to the applicant's own contribution and amounts to a maximum of EUR 4 million per project (in exceptional cases up to EUR 10 million). Print media does not receive direct financial support from the federal administration. The main intermediate subsidy for all print media (with the exception of free advertising magazines) is a reduced VAT rate of $7 \%$ instead of $19 \%$. In addition, since 2009, the Federal Minister for Culture and Media has been conducting the "National initiative for print media - newspapers and magazines in democracy", which educates students about the important role of print media in shaping public opinion. Important forms of this education include subscribing to newspapers and magazines for school libraries, organising workshops to raise pupils media competences and holding contests among school youth for the best article. These activities are to build the habit of using the printed media offer [80].

In the case of Italy, in 2016, the media funding system was fundamentally reorganised. Media co-financing tasks were entrusted in accordance with the 2016 Act [81] to the Plural Information and Innovation Fund (Fondo per Pluralismo e Innovazione Dell'informazione), which aims to distribute annually the funds allocated to the media. 
The project was supported by publishers and journalists associations because they expected to introduce fairer distribution criteria. The tasks of the fund included, among others, ensuring the implementation of the principles set out in Article 21 of the Constitution in the field of rights, freedom, independence and pluralism of information, support for innovation in the provision of information and in the distribution and sales process, strengthening the ability of companies in the industry to invest and ensure a sustainable position on the market, as well as the development of new publications. The fund is inended for press publishers, as well as local radio and television broadcasters. The newspapers of political parties and trade unions, and those of large publishers and companies listed on the stock exchange, as well as specialist press titles and scientific publications were excluded from the possibility of obtaining support. Co-financing can not exceed $50 \%$ and depends, inter alia, on the amount of effort. The fund consists of state funds for newspapers and magazines (in 2016 EUR 154.8 million), state funds for local radio and television stations (EUR 49.5 million in 2016), funds allocated to RAI (a maximum of EUR 100 million), a solidarity fund $-0,1 \%$ from the revenues of the advertising industry, including from advertisements in dailies and magazines, radio, television and digital media [82]. In 2016, direct contribution from the fund was given to 47 titles / press offices, of which the most, more than one-third of the funds (31.98\%), was allocated to "Avvenire", "Libero" and "Italia Oggi" [43]. It is worth mentioning that the distribution of resources is controversial in itself.

Indirect subsidies for the media in Italy deserve special attention. Until 2010, they could take the following forms: loans for publishing companies, tax credits for the purchase of print paper, support for local radio and television broadcasters. Currently, indirect subsidies have been significantly reduced and state aid is basically limited only to support for the press in the form of subsidies for distribution [83]. This form of help can be granted to all titles, regardless of their profile. Financial resources are also received by dominant titles on the market issued by corporations, including "La Repubblica", "Il Corriere della Sera" or "Il Sole 24 Ore" [84]. Another form of assistance that the press can obtain consists of subsidies for interest on loans for restructuring and modernisation. In addition, local radio and TV broadcasters may benefit from a $50 \%$ reduction in charges for telephone and postal services. A system of discounts for advertisers is an interesting form of support for print media and local broadcasters.

In Italy, as in other analysed countries, film productions are supported by a budget of EUR 115 million per year. The support takes the form of a $25 \%$ tax credit for qualified production expenses and up to $100 \%$ tax exemption for taxable income invested in the production and distribution of films. One of the conditions for obtaining co-financing is the passage of the so-called cultural test. Film productions may also receive co-financing from the regional administration [85].

\section{Conclusion}

The directions of media market development observed in the first decades of the 21st century have not diminished the interest of democratic states in ensuring media pluralism. This value remains one of the main goals of media policy in the analysed countries.

This goal is extremely difficult to implement due to the connections of the media world with the world of politics and economy. In all analysed countries, these relation- 
ships exist. The network of connections has not been limited despite the regulations being introduced, i. e. the ban on politicians owning media. In this context, one cannot forget about the pressures imposed on journalists by media owners regarding the conveyed content.

For the countries with political and economic elite connections to the media, as indicated in the text, the best recommendation is to use economic forms of supporting media pluralism. All of the countries discussed in the text decided to use them. The solutions adopted by them can be reduced to subsidies provided to ensure the most diverse publishing offer (in terms of issues or forms of presentation) and diversification of the market structure (titles and press publishers). It should be emphasised that subsidies, as Rasmus Kleis Nielsen put it, "remain 'frozen in their late-20th-century form' $<\ldots>$ First, they remain structured around inherited conceptual distinctions between different forms of delivery (broadcast and print). Second, the vast majority of the public funds used directly and indirectly to support media operations continue to be channelled to legacy players that have grown out of the previously technologically distinct media markets of broadcasting and print" [86, p. 128].

The scope of media support in individual countries is different. France and Austria support their media to the largest extent. In its activities, France concentrates on printed media, and both prestigious and boulevard titles can count on state aid. Indirect and direct subsidies are used. In the case of Austria, subsidies are addressed to both print and electronic media, but restrictions have been introduced so that the dominant titles could not benefit from the aid. Direct subsidies are the most often used form of support. In the case of both countries, the regional and local media remained a particularly prominent group.

This category of beneficiaries was also specified in Italy. For this country, the level of media support can be defined as moderate. Only a few years ago, the state began to pursue an active policy in this area. However, due to the economic crisis, it was decided to reorganise forms of media support. Both print and electronic media can get direct help in the latter case regional and local broadcasters. However, indirect subsidies have been significantly reduced.

To the smallest extent, economic interventions on the media market are made by Germany and the Czech Republic. In both countries, the reduced VAT rate remains the most important form of assistance to the media. In addition, magazines important for culture are supported in the Czech Republic, whereas in Germany reading is promoted. It should be stressed, however, that in the case of Germany, the decisions of the Länder, which run their own media policy, are also important to support the media.

What deserves special attention is the support of the media through advertising of public and state institutions. This form of indirect subsidies is used in all countries, however, regulated in detail in Austria and Italy. Still, this did not reduce the controversy regarding the distribution of funds between media and the amount of expenses.

It is extremely difficult to assess the extent of the impact of public funds and whether they really serve to ensure the diversity of views $[87$, p. 48]. The functioning of magazines that play an important role in the public debate and of politically diverse media that address social or cultural issues is an indirect proof of the legitimacy of this kind of support. Probably, however, some of these media would function even in the case of a suspension of public aid. 
In addition to positive assessments of the impact of public funds, we should also point out the negative ones. Not only niche titles, but also those with significant market positions benefit from public aid. This leads sometimes to assessments that subsidies "do not satisfy the journalistic needs, they only support the dominant newspapers and do not encourage subsidies to invest either in quality or in order to improve the competitive position" [88, p. 94]. It is enough to mention that they are used by dailies with the largest nationwide circulation in Austria: "Neue Kronenzeitung" and "Kurier", in Italy "Repubblica", "Corriere", "Sole 24 Ore", "La Stampa". It is also critically assessed that the support also applies to boulevard media, as is the case in France. However, the importance of media pluralism encourages democratic states to use this tool of media policy. Certainly, it guarantees the possibility of existence of unprofitable titles that enrich the public debate.

\section{References}

1. Karppinen K. Against naive pluralism in media politics: on the implications of the radical-pluralist approach to the public sphere. Media, Culture\&Society, 2007, vol. 29 (3), pp. 495-508. DOI: $10.1177 / 0163443707076192$.

2. Puppis M. Introduction. Media Regulation in Small States. The International Communication Gazette, 2009, vol. 71 (1-2), pp. 7-17.

3. Czaputowicz J. Wprowadzenie. Potencjał konstruktywizmu w wyjaśnieniu integracji europejskie [Introduction. The potential of constructivism in explaining European integration]. Zastosowanie konstruktywizmu $w$ studiach europejskich [The use of constructivism in European studies]. Ed. by Jacek Czaputowicz. Warszawa, Wydawnictwo Uniwersytetu Warszawskiego, 2016, pp. 7-30.

4. Creswell J.W. Qualitative inquiry and research design: Choosing among five approaches. Thousand Oaks, CA, Sages, 2013. 472 p.

5. Bennett A. Case Study Methods: Design, Use, and Comparative Advantages. Models, numbers, and cases: Methods for studying international relations. Eds Detlef F. Sprinz, Yael Wolinsky-Nahmias. Ann Azbor, University of Michigan Press, 2004, pp. 19-55.

6. Levy J. S. Case Studies: Types, Designs, and Logics of Inference. Conflict Management and Peace Science, 2008, vol. 25, pp. 1-18.

7. Lijphart A. Comparative Politics and the Comparative Method. The American Political Science Review, 1971, vol 65, no. 3, pp. 682-692.

8. Jas-Koziarkiewicz M., Stasiak-Jazukiewicz E. Przeciwdziałanie koncentracji mediów w wybranych państwach członkowskich i Unii Europejskiej - analiza rozwiązań prawnych [Counteracting media concentration in selected member states and the European Union - analysis of legal solutions]. Przeglad Politologiczny [Political Science Review], 2018, no. 1, pp. 147-162. DOI:10.14746/pp.2018.23.1.10.

9. Karppinen K. Media Diversity and the Politics of Criteria Diversity Assessment and Technocratisation of European Media Policy. Nordicom Review, 2006, no. 27, pp. 53-68.

10. Just N. Measuring media concentration and diversity: new approaches and instruments in Europe and the US. Media, Culture\&Society, 2009, vol. 31, pp. 97-117. DOI: 10.1177/0163443708098248.

11. Gálik M. Regulating Media Concentration within the Council of Europe and the European Union. Media Freedom and Pluralism, ed. by Beata Klimkiewicz. Available at: http://books.openedition.org/ ceup/2179 (accessed: 03.09.2017).

12. Ciaglia A. Pluralism of the system, pluralism in the system: Assessing the nature of media diversity in two European countries. The International Communication Gazette, 2003, no. 75 (4), pp. 410-426.

13. Klimkiewicz B. Zderzenie standardów racjonalności? Pluralizm mediów w europejskiej polityce medialnej [The Clash of Rationalities? Media Pluralism in European Regulatory Policies]. Global Media Journal-Polish Edition, 2006, no. 1, pp. 2-12.

14. Valcke P. Challenges of Regulating Media Pluralism in the European Union: the Potential of RiskBased Regulation. Quaderns del CAC Challenges of the European audiovisual 38, 2012, vol. XV (1), pp. 2535. Available at: https://www.cac.cat/pfw_files/cma/recerca/quaderns_cac/Q38_valcke_EN.pdf (accessed: 12.12.2017).

15. McQuail D. Media performance: Mass communication and the public interest. London, Sage, 1992. $350 \mathrm{p}$. 
17. Klimkiewicz B. Introduction. Structural Media Pluralism. International Journal of Communication, 2010, no. 4, pp. 906-913.

16. Hallin D. C., Mancini P. Comparing Media Systems: Three Models of Media and Politics. Cambridge, Cambridge University Press, 2004. 360 p.

18. Kowalski T. Koncepcje pluralizmu mediów i polityki mediowej w warunkach rozwoju platform cyfrowych [The concepts of media pluralism and media policy under the conditions of the development of digital platforms]. Studia Medioznawcze [Media Studies], 2017, vol. 2 (69), pp. 21-28.

19. Ossowski Sz. Pluralizm w mediach a wolność wyboru jako fundament liberalnej demokracji [Pluralism in the media and freedom of choice as the foundation of liberal democracy]. Srodkowoeuropejskie Studia Polityczne [Central European Political Studies], 2005, no. 1, pp. 25-38. Available at: http://dx.doi. org/10.14746/ssp.2005.1.03 (accessed: 12.12.2017).

20. Gibbons T. Active Pluralism: Dialogue and Engagement as Basic Media Policy Principles. Global Media Journal-Polish Edition, 2015, no. 9, pp. 1382-1399.

21. Stasiak-Jazukiewicz E. Wstęp [Introduction]. Polityka medialna w Unii Europejskiej [Media Policy in the European Union], Ewa Stasiak-Jazukiewicz, Marta Jas-Koziarkiewicz. Warszawa, Wydawnictwo Poltex, 2011, pp. 13-17.

22. Iosifides P. Methods of measuring media concentration. Media, CulturedSociety, 2007, vol. 19, pp. 643-663.

23. Kaitatzi-Whitlock S. Pluralism and Media Concentration in Europe. Media Policy as Industrial Policy. European Journal of Communication, 1996, vol. 11 (4), pp. 453-483.

24. A comparative analysis of media freedom and pluralism in the EU Member States, Study for the Libe Committee, European Parliament Policy Department C: Citizens' Rights and Constitutional Affairs, 2016. Available at: http://www.europarl.europa.eu/RegData/etudes/STUD/2016/571376/IPOL_STU(2016)571376_EN.pdf (accessed: 03.09.2017).

25. Von Dohnanyi J. The Impact of Media Concentration on Professional Journalism. The Impact of Media Concentration on Professional Journalism, Johannes Von Dohnanyi with cooperation Christian Möller. Vienna, Representative On Freedom Of The Media, 2003. 208 p.

26. Arystoteles. Polityka [The Politics]. Warszawa, Wydawnictwo Naukowe PWN, 2006. 232 p.

27. Åslund A. Comparative Oligarchy: Russia, Ukraine and the United States. CASE Network Studies and Analyses, 2005, no. 296. Available at: http://ssrn.com/abstract=1441910 (accessed: 20.07.2018).

28. European Parliament resolution on the risks of violation, in the EU and especially in Italy, of freedom of expression and information (Article 11(2) of the Charter of Fundamental Rights) (2003/2237(INI)). Official Journal of the European Union, C 104 E, 30.04.2004, pp. 1026-1040.

29. Åslund A. Oligarchs, Corruption, and European Integration. Journal of Democracy, 2014, no. 25 (3), pp. $64-73$.

30. Waschková Císařová L., Metyková M. Better the Devil You Don’t Know: Post-Revolutionary Journalism and Media Ownership in the Czech Republic. Medijske Studije [Media Studies], 2015, vol. 6 (11), pp. 6-18.

31. Zatloukal J. Flaws in the Czech political culture. London, Reuters Institute Fellowship Paper University of Oxford, The Wincott Foundation, 2014. 25 p.

32. Media. Available at: http://www.pentainvestments.com/pl/investments/category/media-7XJAtt.aspx (accessed: 20.02.2018).

33. Stetka V. Between a Rock and a Hard Place? International Journal of Communicatio, 2010, no. 4, p. 865-885.

34. Sławińska T. Mariaż druku i cyfryzacji na francuskim rynku prasowym [Print and digitization marriage on the French press market]. Kraków, Instytut Dziennikarstwa, Mediów i Komunikacji Społecznej, 2016. 200 p. Available at: http://www.media.uj.edu.pl/documents/1384650/134373778/mariaz-druku-i-cyfryzacji.pdf/259c00ad-d889-48da-93fe-4fbe6745d159 (accessed: 20.02.2018).

35. Anteile der Medienangebote und Medienkonzerne am Meinungsmarkt der Medien in Deutschland. [Shares of media offerings and media companies in the opinion market of the media in Germany]. Medien Vielfalts Monitor [Media Diversity Monitor], 2017, vol. 10. Available at: https://www.die-medienanstalten.de/ fileadmin/user_upload/die_medienanstalten/Themen/Forschung/Medienkonvergenzmonitor/DLM_MedienVielfaltsMonitor.pdf (accessed: 20.02.2018).

36. Stasiak-Jazukiewicz E. Zmiana paradygmatu? Niemiecki system medialny [A paradigm shift? German media system]. Warszawa, Wydawnictwo Elipsa, 2013. 240 p.

37. Ehrenkodex für die österreichische Presse [Code of Ethics for the Austrian Press]. Available at: http:// www.presserat.at/show_content.php?hid=2 (accessed: 20.02.2018). 
38. Seethaler J. Austria. Available at: http://monitor.cmpf.eui.eu/mpm2015/results/austria/ (accessed: 20.02.2018).

39. Loi du 29 mars 1935 relative au statut professionnel des journalists [Journalist Professional Statute Act, passed on 29 March 1935]. Journal officiel de la République française, 30.03.1935, p. 3595.

40. Petitjean O. The right to know under threat. Democratic Information in an Age of Corporate Power, 09/2016, no. 14, pp. 12-38.

41. Anzahl der Redakteure und Volontäre bei Tages- und Wochenzeitungen in Deutschland in den Jahren 2012 bis 2017 [Number of editors and volunteers in daily and weekly newspapers in Germany 2012-2017]. Available at: https://de.statista.com/statistik/daten/studie/245562/umfrage/redakteure-und-volontaere-beiden-tages-und-wochenzeitungen/ (accessed: 20.07.2018).

42. Röper H. Zeitungsmarkt 2012: Konzentration erreicht Höchstwert [Newspaper Market 2012: Concentration reaches its highest level]. Media Perspektive, 2012, no. 5, pp. 268-285.

43. Santoro P. L. Finanziamenti all'Editoria nel 2016 [Funding for Publishing in 2016]. Available at: http:// www.datamediahub.it/axzz5AnlcIK5K (accessed: 20.03.2018).

44. Available at: https://www.bundesregierung.de/Webs/Breg/DE/Bundesregierung/BeauftragtefuerKulturundMedien/medien/deutscheWelle/_node.html (accessed: 20.02.2018).

45. Available at: https://www.bundesregierung.de/Webs/Breg/DE/Bundesregierung/BeauftragtefuerKulturundMedien/beauftragte-fuer-kultur-und-medien.html (accessed: 20.02.2018).

46. Zákon č. 159/2006 Sb. o střetu zájmů [Act of Law No. 159/2006 Coll., of March, 16th 2006, on Conflict of Interests], as amended, last amendment in 2017. Available at: https://www.zakonyprolidi.cz/cs/2006-159 (accessed: 20.02.2018).

47. VAT. Available at: https://czechrepublic.trade.gov.pl/pl/abc-biznesu-przewodnik/podatki/5651,vat. html (accessed: 26.03.2018).

48. Available at: https://www.friedespringerstiftung.de (accessed: 20.02.2018).

49. Relazione annuale 2017 sull'attività svolta e sui programmi di lavoro [Annual Report 2017 on the activity performed and work programmes]. Autorità per le garanzie nelle comunicazioni. 2017. Available at: https://www.agcom.it/documents/10179/3058729/RELAZIONE+ANNUALE+2017_documento+completo. pdf/2021e7ba-8250-4239-9a46-5d82fdbf702c (accessed: 12.12.2017).

50. Media ownership - Market realities and regulatory responses. Ed. by Maja Cappello. IRIS Special. Strasbourg, European Audiovisual Observatory, 2016. 128 p.

51. Legge 20 luglio 2004, n 215 Norme in materia di risoluzione dei conflitti di interessi [Law no. 215. 20 July 2004, Provisions concerning the resolution of conflicts of interests]. Gazzetta Ufficiale, 2004, no. $193,18.08$.

52. Cornia A. TV-centrism and politicisation in Italy: obstacles to new media development and pluralism. Media, CultureßSociety, 2016, vol. 38 (2), pp. 175-195. DOI: 10.1177/0163443715594035.

53. Bundesverfassungsgesetz über die Transparenz von Medienkooperationen sowie von Werbeaufträgen und Förderungen an Medieninhaber eines periodischen Mediums (BVG Medienkooperation und Medienförderung - BVG MedKF-T) [Federal Constitutional Act on Transparency in Media Cooperation and of Advertising Orders and the Funding of Media Owners of a Periodical Medium (Federal Constitutional Act on Media Cooperation and Media Funding)]. BGBl, nr 125/2011.

54. Available at: https://www.medien-transparenz.at (accessed: 12.03.2018).

55. Öffentliche Hand: Ausgaben für Werbung steigen weiter [Public sector: Expenditure on advertising continues to rise]. Available at: https://diepresse.com/home/politik/innenpolitik/4823250/OeffentlicheHand_Ausgaben-fuer-Werbung-steigen-weiter (accessed: 20.02.2018).

56. Ettl-Huber S., Roither M. Media in Austria - Small Landscape, Big Influence. Naukowy Przegląd Dziennikarski, 2012, vol. 1 (4), pp. 96-117.

57. Sim P., Skrabal F. Land der Regierungsinserate [Country of government advertisements]. Available at: https://www.dossier.at/dossiers/inserate/land-der-regierungsinserate (accessed: 20.02.2018).

58. Decreto legislativo 31 luglio 2005, n. 177 Testo unico della radiotelevisione [Legislative Decree no 177 of 31 July 2005 the Italian Audiovisual Media Service Law]. Gazzetta Ufficiale, 2005, no. 208, 07.09, as amended, last amendment in 2010.

59. Gitlin T. Media Unlimited: How the Torrent of Images and Sounds Overwhelms Our Lives. New York, Metropolitan Books, 2002. 264 p.

60. Herman E.S., Chomsky N. Manufacturing Consent: The Political Economy of the Mass Media. New York, Pantheon Books, 2002. 480 p.

61. Gamble A., Watanabe T. A Public Betrayed: An Inside Look at Japanese Media Atrocities and Their Warnings to the West. Washington, An Eagle Publishing Company Regnery Publishing, 2004. 464 p. 
62. Jakubowicz K. Polityka medialna a media elektroniczne [Media Policy and Electronic Media]. Warszawa, Wydawnictwa Akademickie i Profesjonalne, 2008. 288 p.

63. Bundes-Verfassungsgesetz [Federal Constitutional Law]. BGBI, Nr 1/1930, as amended, last amendment in 2018. Available at: https://www.ris.bka.gv.at/GeltendeFassung.wxe?Abfrage=Bundesnormen\&Gese tzesnummer $=10000138$ (accessed: 12.03.2018).

64. Bundesgesetz über die Förderung politischer Bildungsarbeit und Publizistik (Publizistikförderungsgesetz 1984 - PubFG) [Federal Act on subsidies for (PubFG) political educational work and journalism]. Bundesgesetzblatt für die Republik Österreich, 1984, no. 369, as amended, last amendment in 2010.

65. Bundesgesetz über die Förderung der Presse (Presseförderungsgesetz 2004 - PresseFG 2004) [Federal Act on Press Subsidies (Press Subsidies Act 2004)]. Bundesgesetzblatt für die Republik Österreich, 2003, no. 136, as amended, last amendment in 2010.

66. Ergebnisse der Förderung gemäß dem Abschnitt II des Publizistikförderungsgesetzes 1984 im Jahr 2017 [Results of the funding according to section II of the Federal Act on subsidies for (PubFG) political educational work and journalism]. Available at: https://www.rtr.at/en/ppf/PubFErgebnisse/Ergebnisse_der_Publizistikfoerderung_II_im_Jahr_2017.pdf (accessed: 18.03.2018).

67. Ergebnisse der Presseförderung im Jahr 2017 [Results of press support in 2017]. Available at: https:// www.rtr.at/de/ppf/Uebersicht2017 (accessed: 18.03.2018).

68. Jas-Koziarkiewicz M. Pomoc publiczna dla mediów w Austrii [Forms of public support for the media in Austria]. Systemy medialne w XXI wieku. Wspólne czy różne drogi rozwoju? [Media systems in the $21^{\text {st }}$ century. Common or different ways of development?]. Eds Janusz Adamowski, Alicja Jaskiernia. Warszawa, Oficyna Wydawnicza ASPRA-JR, 2012, pp. 176-191.

69. Available at: https://www.rtr.at/de/ffat/Fernsehfonds (accessed: 12.03.2018).

70. Available at: https://www.rtr.at/de/foe/EntscheidungenNKRF (accessed: 12.03.2018).

71. Kommunikationsbericht 2016 Wir Stehen Für Wettbewerb Und Medienvielfalt [Communication Report 2016 We stand for competition and media diversity]. Available at: https://www.rtr.at/de/inf/KBericht2016/KBericht_2016.pdf (accessed: 18.03.2018).

72. Available at: https://www.filmstandort-austria.at/about/index.php?lang=DE (26.03.2018).

73. Zákon č. 239/1992 Sb. o Státním fondu kultury České republiky [Act No. 239/1992 Coll., on the State Cultural Fund of the Czech Republic], as amended, last amendment in 2011. Available at: https://www.zakonyprolidi.cz/cs/1992-239 (accessed: 12.03.2018).

74. Zákon č. 496/2012 Sb., o audiovizuálních dílech a podpoře kinematografie a o zmèně některých zákonu (zákon o audiovizi), ze dne 26. ř́jna 2012 [Act No 496/2012 Coll., on the audiovisual works and on the support of the cinematography and on amendments of other laws], as amended, last amendment in 2017. Available at: https://www.zakonyprolidi.cz/cs/2012-496 (accessed: 12.03.2018).

75. Available at: http://www.filmcommission.cz/cs/ (accessed: 26.03.2018).

76. Présentation du Fonds stratégique pour le développement de la presse [Presentation of the Strategic Fund for Press Development]. Available at: http://www.culturecommunication.gouv.fr/Thematiques/Presse/ Aides-a-la-presse/Le-Fonds-strategique-pour-le-developpement-de-la-presse-aides-directes/1.-Presentation-du-Fonds-strategique-pour-le-developpement-de-la-presse2 (accessed: 10.09.2017).

77. Wojciak T. $130.18 \mathrm{M} €$ d'aides directes et individuelles pour la presse en 2015 [130.18 Million Euro of direct and individual support for the press in 2015]. Available at: http://www.cbnews.fr/etudes/13018-meurd-aides-directes-et-individuelles-pour-la-presse-en-2015-a1030813 (accessed: 10.09.2017).

78. Trip (tax rebate for international production). Available at: http://www.filmfrance.net/v2/gb/home. cfm?choixmenu=taxrebate (accessed: 26.03.2018).

79. Deutscher Filmförderfonds - Grütters: Deutschland bleibt starker Standort für nationale und internationale Filmproduktionen [German Film Fund - Grütters: Germany remains a strong location for national and international film productions]. Available at: http://www.dfff-ffa.de/index.php?pressemitteilungen\&ne wsdetail=20180209-1_deutscher-filmfoerderfonds-gruetters-deutschland-bleibt-starker-standort-fuer-nationale-und-internationale-filmproduktionen (accessed: 18.03.2018).

80. Nationale Initiative Printmedien - Zeitungen und Zeitschriften in der Demokratie [National Initiative Print Media - Newspapers and Magazines in Democracy]. Available at: https://www.bundesregierung.de/ Webs/Breg/DE/Bundesregierung/BeauftragtefuerKulturundMedien/medien/medienkompetenz/nationaleInitiativePrintmedien/_node.html (accessed: 20.02.2018).

81. Legge 26 ottobre 2016, n. 198 Istituzione del Fondo per il pluralismo e l'innovazione dell'informazione e deleghe al Governo per la ridefinizione della disciplina del sostegno pubblico per il settore dell'editoria e dellemittenza radiofonica e televisiva locale, della disciplina di profili pensionistici dei giornalisti e della composizione e delle competenze del Consiglio nazionale dell'Ordine dei giornalisti. Procedura per l'affidamento in concessione del servizio pubblico radiofonico, televisivo e multimediale [Law of 26 October 
2016, no. 198 Establishment of the Fund for pluralism and innovation and powers to the Government to redefine the discipline of public support for publishing and broadcasting radio and local television, the discipline of pension profiles of journalists and the composition and competence of the national Council of journalists. Procedure for the concession of public service radio, television and multimedia]. Gazzetta Ufficiale, 2016, no. 255, 31.10 .

82. Norme sul sostegno all'editoria e all'informazione, Dossier n. 173 [Rules on support for publishing and information, Dossier n. 173]. Ufficio Documentazione e Studi [Documentation and Studies Office], ottobre 2016, no. 4. Available at: http://deputatipd.it/files/documenti/173_Norme\%20sul\%20sostegno\%20 editoria\%20informazione.pdf (accessed: 26.03.2018).

83. Atte A. Contributi per l'editoria: ecco come fare per ottenerli [Subsidies for publishing houses: how to get them]. Available at: https://www.money.it/Contributi-per-l-editoria-ecco (accessed: 20.03.2018).

84. Come cambiano i contributi pubblici ai giornali [How did the public subsidies for newspapers change?]. Available at: https://www.ilpost.it/2017/03/27/giornali-soldi-pubblici/ (accessed: 20.03.2018).

85. Available at: http://www.filminginitaly.com/tax_credit (accessed: 26.03.2018).

86. Nielsen R. K. 'Frozen' media subsidies during a time of media change: A comparative analysis of media policy drift in six Western democracies. Global Media and Communication, 2014, vol. 10 (2), pp. 121138.

87. Ecoplan. Evaluation der Presseförderung seit 2008 und alternativer Modelle [Evaluation of press subsidies since 2008 and alternative models]. Schlussbericht 22, Dezember 2010. 72 p.

88. Trappel J. Medienförderung: Ein Komplementärinstrument der schweizerischen. Medienpolitik? Konzepte zur Vielfaltssicherung und Erfahrungen aus Österreich [Media Promotion: A complementary instrument of the Swiss. Media Policy? Concepts for diversity assurance and experiences from Austria]. Das schweizerische Mediensystem im Wandel. Herausforderungen, Chancen, Zukunftsperspektiven [The Swiss media system in transition. Challenges, opportunities, future perspectives]. Hg. Künzler M. Bern, Stuttgart, Wien, Haupt, 2005, pp. 77-97.

Received: April 15, 2018

Accepted: October 1, 2018

Author's information:

Marta Jas-Koziarkiewicz _ PhD, Assistant Professor; martajas@uw.edu.pl

Ewa Stasiak-Jazukiewicz — Full Professor; e.stasiak@uw.edu.pl 